\title{
Fair Value in the Islamic Perspective: Jakarta Islamic Index (JII) Companies' Cases
}

\author{
Maisya Pratiwi ${ }^{1}$, Dodik Siswantoro $^{1 *}$ \\ ${ }^{1}$ Faculty of Economics and Business, Universitas Indonesia, Depok 16424, Indonesia \\ *dodik.siswantoro@ui.ac.id
}

\begin{abstract}
This study aims to determine whether the companies listed in the Jakarta Islamic Index (JII) have assets or liabilities that are measured at fair value, where assets or liabilities measured in this way are likely to be used to form the basis of measurement of corporate zakat. This study uses companies listed in the JII because these companies have fulfilled Islamic requirements in terms of both products sold and financial issues. Companies listed in the JII are expected to have greater awareness about using fair value than using historical cost. The findings from 15 companies reveal that most of the companies listed in the JII use fair value measurement. The majority of the fair value used by the sample company is hierarchy 1 and 2 fair value.
\end{abstract}

Keywords: Fair Value; Islamic Perspective; Zakat; Stock; Hierarchy.

\section{INTRODUCTION}

The study of measurements in most Islamic accounting literature relates to measurements in the determination of zakat. In the Islamic perspective, it is stated that the measurement of assets or liabilities as the basis of zakat determination emphasizes the use of fair value measurement rather than historical cost. This indicates that fair value measurement is very important in the perspectives of Islam because it will produce information that is in accordance with current conditions without misleading the users of this information.

The measurement of fair value is even explained in the Qur'an, although only in relation to agricultural zakat. Agricultural zakat is closely related to asset measurement. In Al-Qur'an, Al-An'am chapter 6 verse 141 describes zakat related to agriculture. The meaning is:

...but render the dues that are proper on the day that the harvest is gathered......

Surah Al-An'am verse 141 is related to paying zakat when collecting an agricultural harvest. It is certainly necessary to measure agricultural yields when agricultural products are obtained to become the basis of zakat determination. These statements explain that the agricultural products or assets are valued based on their current market value, or so-called fair value. This underlines the fact that the measurement of the fair value of assets or liabilities is strongly emphasized in the Islamic perspective. Many scholars have interpreted this verse as indicating the urgent need to value assets on the fresh harvest. This immediate value would be better than the value calculated a few days after the harvest, although this is also subject to the type of harvest. It also implies that for zakat payment, Muslim must use the best value of the zakat-able assets so the value does not decrease.

All parties who are obliged to pay zakat must be clearly informed of the urgency of zakat measurement to obtain a precise value. This may have implications for other issues, such as financial statement presentation. As zakat is based on the financial statement approach, it would be better if companies also referred to the zakat calculation approach, which uses fair value for assets and liabilities.

In addition, AAOIFI (the Accounting and Auditing Organization for Islamic Financial Institutions) ${ }^{1}$ explained that the calculation of zakat requires the calculation of assets and liabilities through fair value (Cash Equivalent Value) to be used as the basis for the imposition of zakat. It indicates that the more accurate measurement of assets using fair value is the equivalent cash value of the Islamic perspective, so that the measurement of fair value does not provide uncertainty about whether the current price figure relates to the current condition of the assets and liabilities.

Regardless of whether the company actually carries out zakat, this study aims to determine whether a company listed in the JII has assets or liabilities that are measured at fair value, in which the assets or liabilities measured at such fair value are likely to be used as the basis for the imposition of corporate zakat. This study uses companies listed in the JII because these companies fulfill Islamic requirements in terms of both products sold and financial affairs. Companies listed in the JII are expected to be aware that the Islamic perspective emphasizes the use of fair value rather than historical cost.

Analysis of the results from 15 companies indicates that the companies listed in the JII use fair value more than other approaches. The majority of the fair value used by the sample companies was hierarchy 1 and 2 fair 
value. This indicates that companies listed in the JII have more awareness about using fair value than using historical cost.

This paper is presented in the following structure: the first section is the introduction. The second section provides a literature review. The third section presents an overview of research methods. The fourth section presents the research results. The fifth section discusses the conclusion.

\section{LITERATURE REVIEW}

In investigation of the measurement of assets or liabilities in the Islamic perspective, the determination of zakat is a key issue. Islahi and Obaidullah ${ }^{2}$ stated that fixed assets are exempted from the determination of zakat. In the Hadith (the sayings of the prophet), the prophet Muhammad PBUH explains how to measure assets or goods before zakat is paid. The meaning of the hadith is:

"measure based on the price today, then pay zakat".

Unfortunately, the hadith is weak because the isnad (the chain of transmitters) of this hadith cannot be traced, although it has similar meaning to the Qur'an of Al-An'am 141. This hadith concerns not only agricultural products, as described in Surah Al-An'am 141, but all businesses. The hadith also emphasizes the measurement of goods or assets based on current price conditions. It certainly expresses that fair value is the suggested measurement in the Islamic perspective.

Fair value is further described in PSAK 68 as follows: "fair value as the price to be received to sell an asset or price to be paid to transfer a liability in a regular transaction between market participants on the date of measurement". Majercakova and Skoda ${ }^{3}$ argue that fair value is divided into three hierarchies depending on inputs for asset valuation and liability techniques. In the hierarchy of fair value, the highest priority is hierarchy 1 fair value, where the measurement used is based on price quotes (without adjustment) in the active market, thereby providing a reliable measure for identical assets or liabilities that the entity can access on the date of measurement (see Figure 1).

Hierarchy 2 fair value is the measurement of fair value using observable prices for assets or liabilities, either directly or indirectly, in addition to quotes in Level 1. Adjustments to Level 2 inputs depend on factors specific to assets or liabilities, such as conditions or the location of the asset, the level at which the input is related to an item proportional to the asset or liability, and the volume or level of activity in the market where inputs can be observed. Observable prices are interest rate, credit risk, and default rate.

Hierarchy 3 fair value is a measurement of fair value at a price that cannot be observed for assets or liabilities using the best available information. Inputs that cannot be observed where market data is not available thus require development on the basis of the best available information on the assumption that market participants appreciate the asset. This measurement uses assessment estimates.

From this type of fair value, a company would usually conveniently refer to level 1 or level 2 fair value for some purposes, but not for level 3. Level 3 fair value requires professional judgment, which incurs large expenses, as it requires independent review to estimate the value.

On the other hand, there are tax consequences if there is an increase in price when revaluing the asset. If the impact is not beneficial, the company would be reluctant to use fair value for their assets. This requires government policy to consider issues of tax on revalued assets which does not add cash received to the company.

\begin{tabular}{|l|l|}
\hline Level & \multicolumn{1}{|c|}{ Description } \\
\hline 1 & $\begin{array}{l}\text { Quoted price quotes (without adjustment) in } \\
\text { the active market }\end{array}$ \\
\hline 2 & $\begin{array}{l}\text { Observable prices for assets or liabilities, } \\
\text { either directly or indirectly }\end{array}$ \\
\hline 3 & $\begin{array}{l}\text { Price that cannot be observed for assets or } \\
\text { liabilities using the best available } \\
\text { information. This measurement uses } \\
\text { assessment estimates }\end{array}$ \\
\hline
\end{tabular}

Fig.1. Fair Value Hierarchy ${ }^{3}$

In the Islamic perspective, Majid and Haliding ${ }^{4}$ state that the measurement of fair value of assets or liabilities will lead to uncertainty (gharar) because hierarchy 1 fair value may be influenced by arbitration actions from investors, and even the measurement of fair value through hierarchies 2 and 3 uses subjective estimates such as assumptions and management judgments. They also state that fair value is not in accordance with Sharia compliance. This opinion may be weak, as it is subject to price fluctuation, which is high. But if there is a significant difference from historical price, it would not be fair for a company to disclose their asset value to 
stakeholders.

However, Shahul ${ }^{5}$ state that fair values may be used in measuring assets or liabilities of fair value as measured by a strong scoring base, so that it cannot be used to meet the personal needs of management. Stakeholders must be informed about fair value adjustment for assets to avoid mispricing asset information. In addition, the fair value adjustment would be meaningless.

The conditions in which the hadith above were issued were different from the current situation. At that time, money was in the form of gold, which is stable and does not fluctuate. Currently, money as a basis of measurement is based on paper and agreements, which can cause fluctuating movement and depreciation. Therefore, it can cause issues in measurement, especially in fair value. This issued has been discussed by Majdi ${ }^{6}$. In fact, in its accounting assumptions, the AAOIFI states that accounting needs monetary stability; otherwise accounting cannot be measured precisely.

The issue here is that calculating the precise value of zakat requires the fair value of assets, as zakat is an act of worship. If the zakat payment is less than the required value, this would be meaningless in the sight of God. This does not occur if the value is more than required. However, a further issue arises in terms of which fair value is used. The ultimate goal is to calculate the precise value that the institution must achieve for their shareholders and stakeholders (see Figure 2).

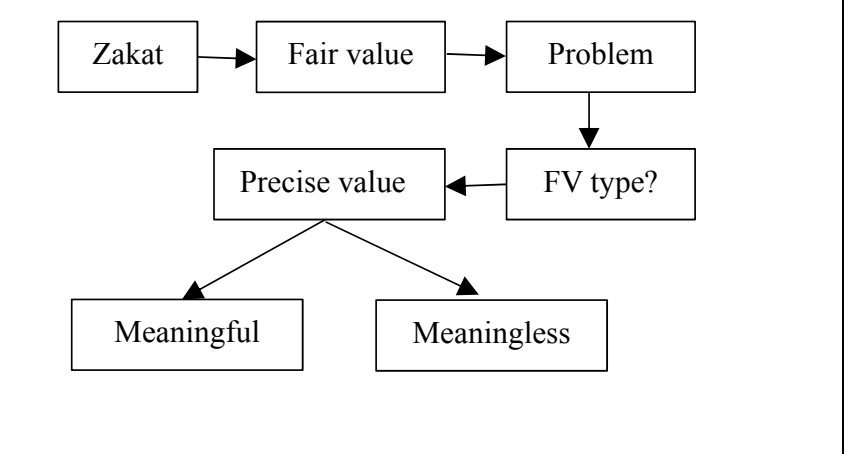

Fig.2. Fair Value and Zakat Requirements

From the stakeholders' point of view, fair value of company assets can be of benefit, as it reveals the real condition of the company. The most important issue is how stakeholders can be fully informed about this fair value asset adjustment.

\section{RESEARCH METHOD}

This population for this research comprises the companies listed in the JII in December 2016. The total number of companies listed in the JII was 30. Nine State-Owned Enterprises (SOEs) were excluded from the sample because they are government-owned companies in which there is no obligation to pay zakat. This left a sample of 21 companies. These companies were ranked by market capitalization and those included in the top 50, which have the largest market capitalization of all companies listed on the Indonesia Stock Exchange, were selected. The final sample thus comprised 15 companies.

We searched each of the companies' financial statements using the keywords "fair value". If the words "fair value" were found in these statements, then we analyzed assets measured by fair value and the assets may be considered to be included in the calculation of corporate zakat. Then, the fair value was analyzed to determine its level in the fair value hierarchy.

The issue of Muslim company owners was omitted here, as it needs further research to calculate zakat assets. However, zakat payments can be calculated based on the Muslim proportion of shares.

\section{RESULTS AND DISCUSSION}

This study analyzed fifteen companies listed in the JII in 2016 that are included in the 50 companies with the largest capitalization in the Indonesia Stock Exchange. The following is the assessment method used by the companies for some of their assets, described in Table 1.

Fixed assets, which are used for companies' operational production, are exempted from zakat determination, so we focus only on asset valuation as measured by fair value other than fixed assets.

Of the fifteen companies analyzed, six did not use fair value measurement to assess their assets during 2016, namely PT Unilever Indonesia Tbk., PT Indocement Tunggal Prakarsa Tbk., PT Matahari Department Store Tbk., PT Vale Indonesia Tbk., and PT AKR Corporindo Tbk. Companies listed in the JII should be aware that fair value measurement is important, but the results state that these six companies still do not use fair value measurement to assess any of their company assets. 
Table.1. Assessment Method

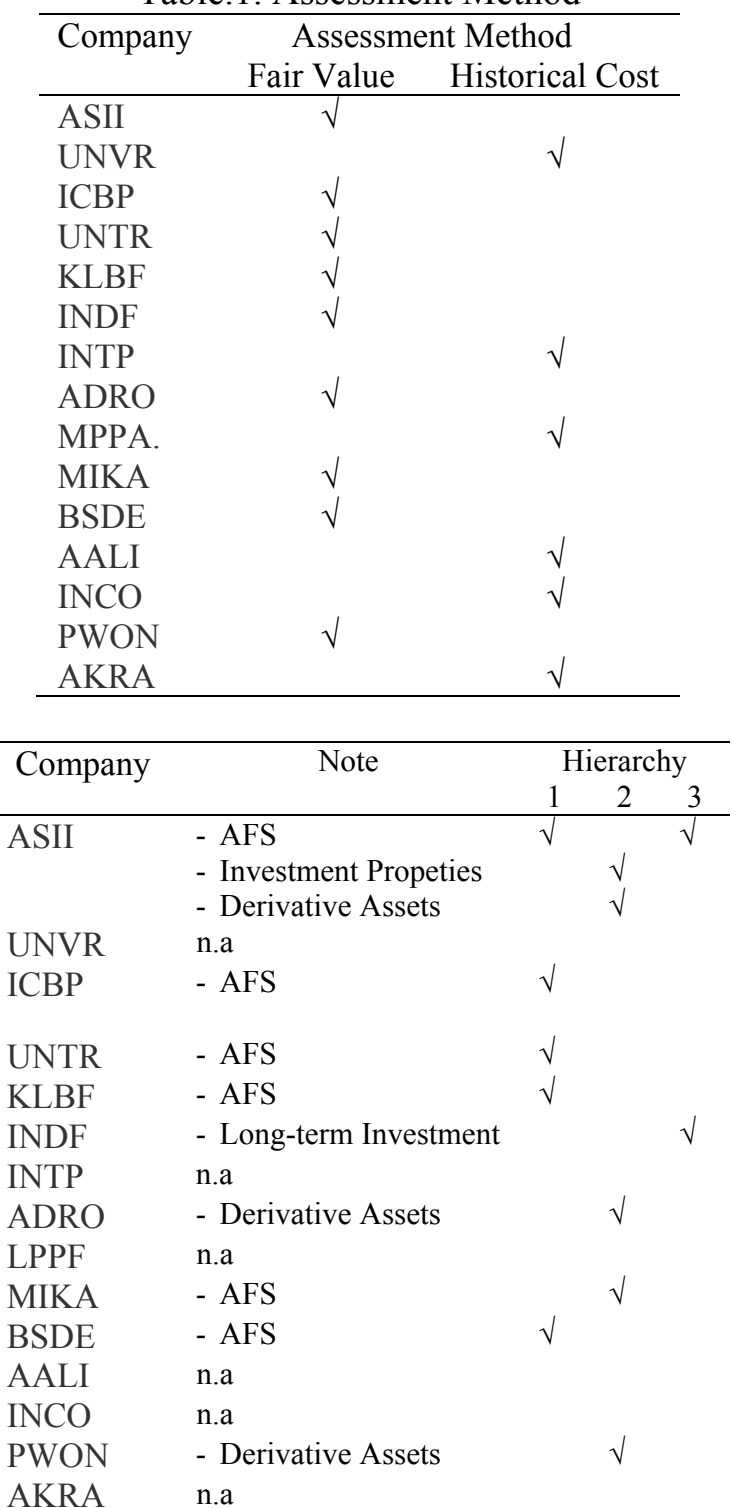

From the fifteen companies used in the analysis, nine used the measurement of fair value in assessing some of their assets. PT Astra International Tbk. used fair value the most for their assets. From the measurement of fair value, it is known that many companies use hierarchy level 1 and 2 fair value compared with hierarchy 3 fair value. This indicates that companies listed in the JII are indirectly also aware that the measurement of fair value is suitable for Sharia. This is in line with Shahul ${ }^{5}$ study from an Islamic perspective, which argued that fair values may be used in the measurement of assets or liabilities when measured using a strong assessment base. Hierarchy 1 and 2 fair value has a stronger valuation base than hierarchy 3 fair value.

Available for Sale (AFS) type 1 was the most frequently used approach, being used by five of the companies in our sample, while levels 2 and 3 were only adopted by one company. Derivative assets all used type 2, which is not available for type 1 .

Fair value level 3 is used by PT Indofood Sukses Makmur, Tbk for long-term investments. This investment value may not available in the market and is observable indirectly.

Some interesting issues arose in relation to companies that do not use fair value. These companies were analyzed as follows:

a. PT Unilever Tbk.

This company focuses on household products, such as soap, shampoo, food, and beverages. The issues here are which price can be used to measure the fair value: the Cost of Goods Sold or Price Value?

b. PT Indocement Tunggal Prakarsa Tbk.

This company produces cement for infrastructure and household use. A similar issue arises - which price can be used to measure the fair value: Cost of Goods Sold or Price Value?

c. PT Matahari Department Store Tbk. 
This company is a supermarket which sells many products in the market, including shoes and clothes. Again, the issue arises of which price can be used to measure the fair value: the Cost of Goods Sold or Price Value?

d. PT Astra Agro Lestari Tbk.

This company produces many types of cooking oil, including palm oil, processed palm oil and final cooking oil. Similar issues arise as to which price can be used to measure the fair value: the Cost of Goods Sold or Price Value?

e. PT Vale Indonesia Tbk.

This company produces mining products, especially nickel. The value of final nickel is available in the market: therefore, it would be accessible in the market.

f. PT AKR Corporindo Tbk.

This company focuses on chemical products, petroleum and its processing. The price may not available in the market. Therefore, specific measurement of its assets is needed.

For the six companies above, the issue of fair value can be identified in terms of which value type can be used for each specific company. If we refer to the AAOIFI, zakat calculation requires Cash Equivalent Value $(\mathrm{CEV})$ as the fair value of zakat-able assets. Therefore, fair value level 2 may be the best quote for zakat valuation and a company may use it in this regard as long as its stakeholders are clearly informed. Furthermore, for specific issues, fair value level 3 can also be used if the price cannot be observed.

\begin{tabular}{|l|l|}
\hline Level & \multicolumn{1}{|c|}{ Description } \\
\hline 1 & $\begin{array}{l}\text { Quoted price quotes (without adjustment) in } \\
\text { the active market }\end{array}$ \\
\hline 2 & $\begin{array}{l}\text { Observable prices for assets or liabilities, } \\
\text { either directly or indirectly }\end{array}$ \\
\hline $2 \mathrm{a}$ & $\begin{array}{l}\text { Cash Equivalent Value which may refer to } \\
\text { observable price. }\end{array}$ \\
\hline 3 & $\begin{array}{l}\text { Price that cannot be observed for assets or } \\
\text { liabilities using the best available } \\
\text { information. This measurement uses } \\
\text { assessment estimates }\end{array}$ \\
\hline
\end{tabular}

Fig.3. Revised Fair Value Hierarchy

From the discussion above, a new hierarchy level can be added, which is level 2a: Cash Equivalent Value. This is not level 2 but the price may be an estimate by the company to see the asset value in cash (Figure 3).

\section{CONCLUSION}

This study aims to determine whether the companies listed in the JII have assets or liabilities that are measured at fair value, where assets or liabilities measured at fair value are likely to be used to form the basis of measurement of corporate zakat. From the fifteen companies analyzed, it was found that six did not use fair value measurement to assess their assets in 2016. This indicates that the companies listed in the JII have not yet realized that fair value measurement is important. Nine companies used fair value to measure some of their assets. The overall results revealed that most of the companies listed in the JII use fair value measurement. The fair value that is most frequently used is level 1 and 2 fair value. Further research can extend these findings by examining whether the fair value used by companies listed in the JII differs from that used by companies that are not listed in the JII.

Cash Equivalent Value (CEV) is a suitable value for zakat valuation. This is because fair value may not be suitable for trading and manufacturing companies, as it is different for sale prices and COGS.

\section{REFERENCES}

[1] AAOIFI. Accounting and auditing standards for Islamic financial institution. Accounting and Auditing Organization for Islamic Financial Institution, Manama (1998).

[2] A. Z. Islahi, O. Mohammed. Zakah on stocks: some unsettled issues. Islamic Economics, 17(2)(2004) 3-17.

[3] D. Majercakova, S. Miroslav. Fair value in financial statements after financial crisis. Journal of Applied Accounting Research, 16(3)(2015) 312-332.

[4] J. Majid, S. Haliding. The critical aspect on fair value accounting and its implication to Islamic financial institutions. Al-Iqtishad, 6(2)(2014) 283-304.

[5] H. Shahul, S. Pramono, B. Alrazi, N. Bahrom. Alternative disclosure \& performance measure for Islamic banks. Proceedings of International Conference on Administrative Sciences, King Fahd University of Petroleum and Minerals, Saudi Arabia (2004).

[6] H. Majdi, D. Siswantoro, J. Brozovsky. The stability of gold dinar and accounting implications: an empirical study. International Islamic University Malaysia, Kuala Lumpur (2002). 